\title{
Milk Production, Marketing and Quality in Meta District of Eastern Hararghe Zone, Ethiopia
}

\author{
Mitiku Eshetu Guya ${ }^{1}$, Mulu Mamo Adugna ${ }^{2} \&$ Yesihak Yusuf Mumed ${ }^{1}$ \\ ${ }^{1}$ School of Animal and Range Sciences, Haramaya University, Ethiopia \\ ${ }^{2}$ Forage Expert of Tiyo District, Arsi Zone, Ethiopia \\ Correspondence: Mitiku Eshetu Guya, School of Animal and Range Sciences, Haramaya University, P.O. Box \\ 138, Dire Dawa, Ethiopia. E-mail: mitikuguya@yahoo.com
}

$\begin{array}{ll}\text { Received: December 5, } 2018 & \text { Accepted: February 2, } 2019 \quad \text { Online Published: April 15, } 2019 \\ \text { doi:10.5539/jas.v11n5p535 } & \text { URL: https://doi.org/10.5539/jas.v11n5p535 }\end{array}$

The research is financed by Swedish International Development Agency (SIDA) under Haramaya University female students'sponsorship scheme.

\begin{abstract}
The study was conducted in Meta District of Eastern Hararge Zone Oromia Regional State, Ethiopia with the objective to assess milk production and marketing, and to determine chemical composition and microbial quality of raw cow milk. Three Rural Kebeles (RK) namely, Biftu Ganama, Oda Chafe and Waligalte Bali'na were purposively selected based on dairy production potential and accessibility. A total of 132 respondents were randomly selected from farmers (122), consumers (6) and milk collection centers (4). Interview was made using semi-structured questionnaire to collect data on milk production, constraints, marketing, milk handling practices and utensils used as milk container. The result of the study indicated that, average daily milk production, milk for marketing and consumption were $1.96 \pm 0.517$ litters/day/cow, $68.9 \%$ and $31.1 \%$, respectively. Majority of the respondents ranked feed shortage as the first constraint. Hand milking after calf suckling was practiced by all the farmers. Most of the respondents (56.6\%) used a gourd container locally called "qabe" for milking, and plastic jerry can $(81.96 \%)$ for milk delivery to milk collection centers. Significantly higher $(P<0.05)$ figures were recorded for fat, protein, total solids, solids-not-fat and lactose contents at producers level than the consumers and collection centers. Total bacterial count (TBC), coliform count (CC) and yeast and mould count (YMC) of milk samples from milk collection centers were significantly higher $(\mathrm{P}<0.05)$ than milk samples from consumers and producers and did not meet quality standards set by Quality Standard Authority of Ethiopia. Therefore, we can concluded that the chemical composition of milk was satisfactory compared to the standard level, whereas the microbial quality of the milk was poor that suggests the need for better sanitary practices of milking environment and milk utensils.
\end{abstract}

Keywords: collection centers, microbiological quality, milk consumers

\section{Introduction}

Dairy plays an important role in the Ethiopian agricultural sector and the national economy (Azage et al., 2013). The sector is a source of livelihoods for a vast majority of the rural population in terms of consumption, income generation and employment. Estimates by the nation's Central Statistical Agency (CSA, 2014) indicate that there are about 55 million cattle, of which $44.6 \%$ are males and $55.4 \%$ are females. The same source further indicated that 2.8 billion liters of milk was produced in 2012-13, out of which $42.3 \%$ was used for household consumption.

The majority of milking cows are indigenous animals which have low production performance with the average age at first calving of 53 months and average calving interval of 25 months. Cows had three to four calves before leaving the herd at 11-13years of age; the average cow lactation milk yield is 524 liters for 239 days of which 238 liters off take for human use while 286 liters is suckled by the calf. There are also a very small number of crossbred dairy cows that are milked to provide the family with fresh milk, butter and cottage cheese. Surpluses are sold, usually by women, who use the regular cash income to buy household necessities or to save for festival occasions (Belete, 2006). 
The milk marketing system is not well developed giving the large majority of smallholder milk producers a limited access to milk market. In 2010 , less than $7 \%$ of the annual milk production was estimated to be marketed at national level. In 2009, there were 180 cooperatives involved in milk production and marketing in the entire nation, accounting for only $2 \%$ of the total number of agro-based cooperatives operating in various parts of the country. In most of the cases, existing dairy cooperatives are operating in areas that are accessible to transportation and markets. This means that a substantial amount of milk does not reach the markets and a number of producers keep on producing at a subsistence level (Zelalem, 2012).

Milk is a complex biological fluid and by its nature, a good growth medium for many microorganisms. Because of the specific production, it is impossible to avoid contamination of milk with microorganisms. Therefore, the microbial content of milk is a major feature in determining its quality (Karmen \& Slavica, 2008). The safety of raw cow milk is influenced by a combination of management and control measures along the entire dairy supply chain. Control of animal health, devotion to good milking practices, and control over milking parlous hygiene are important in reducing the microbial load in raw milk (FSA, 2006).

Microbial contamination in milk may cause milk-borne diseases to humans while others are known to cause milk spoilage. Many milk-borne epidemics of human diseases are spread through milk contamination. Sources of microbial contamination in milk include primary microbial contamination from the infected or sick lactating animal. The secondary causes of microbial contamination occurs along the milk value chain which may include contamination during milking by milkers, milk handlers, unsanitary utensils and/or milking equipments and water supplies used in sanitary activities.

In general, there was no study conducted in the study area about milk production, marketing and quality. The extent, causes and possible remedies of small holder milk producers were yet given poor attention on the production, marketing and quality of milk. As a result, any measure towards improving the dairy productivity may not be in line with the utilization of the available resources and scarce production inputs. This study was considered as a one-step forward towards bridging this gap. Therefore, this study was conducted with the objectives to assess milk production and marketing, to determine chemical composition and microbial quality of milk, and to assess the major constraints of milk production, marketing and quality to suggest possible alternative solutions for improvement in the study areas.

\section{Materials and Methods}

\subsection{Description of the Study Area}

The study was conducted in Meta District of the Eastern Hararge Zone, Oromia Regional State. Meta District is located at $445 \mathrm{~km}$ from the capital Addis Ababa and $80 \mathrm{~km}$ west of Harar town. Meta District is located between $9^{\circ} 0^{\prime} 09^{\prime \prime}$ to $9^{\circ} 0^{\prime} 31^{\prime \prime} \mathrm{N}$ latitude and $41^{\circ} 0^{\prime} 29^{\prime \prime}$ to $41^{\circ} 0^{\prime} 44^{\prime \prime} \mathrm{E}$ longitude (Meta District Livestock Office, 2015). Altitude of Meta District is 2830 meters above sea level. The annual rainfall amount ranges from 600-900 mm and the temperature ranges between $15{ }^{\circ} \mathrm{C}-37{ }^{\circ} \mathrm{C}$. Gara Muleta Mountain, one of the highest mountains in Oromia Regional State, is found in this District (Meta District Livestock Office, 2015).

\subsection{Study Design and Sampling Technique}

The study involved cross-sectional survey method aimed to assess general milk production and marketing, and a laboratory-based investigation aimed to determine the chemical composition and microbial quality of raw cow milk produced and marketed in Meta District. Sample size was determined according to the sampling formula provided by Yamane (1967). It is with $95 \%$ confidence interval at 0.05 level of precision.

$$
\mathrm{n}=\frac{\mathrm{N}}{1+\mathrm{N}\left(\mathrm{e}^{2}\right)}
$$

Where, n: Sample size; N: Population size that have lactating cows; e: level of precision.

The three kebeles (Biftu Ganama, Oda Caffe and Waligalte Bali'na) were purposively selected from Meta District based on milk production potential and accessibility in consultation with District Bureau of Agriculture and other concerned government offices. According to the above formula 122 farmers were selected randomly from the selected kebeles: 41, 40 and 41 farmers from Biftu Ganama, Oda Caffe and Waligalte Bali'na kebeles, respectively. For milk sample collection, 28, 6 and 4 milk samples from producers, consumers and milk collection centers, respectively were collected for laboratory analysis. A total 38 raw milk samples were collected in the morning from producers, at market place from consumers, and after collection from collection centers.

\subsection{Data Collection Methods and Sources}


Primary data collection for survey part was conducted using semi-structural questionnaire by interviewing the randomly selected farmers. Data were collected on milk production, animal feed sources, milking practices, milk handling practices, consumption and marketing, milk storage methods, and milk production and market constraints. Moreover, data were collected on frequency of milking, method of cleaning milk containers, type milk containers used for milking, water source and milk quality control methods.

A total of 38 raw milk samples of $300 \mathrm{~mL}$ were aseptically collected and placed into sterile glass bottles. Subsequently, samples were labeled and put into icebox to restrict microbial multiplication and then transported as early as possible to Haramaya University dairy technology laboratory and stored in refrigerator at $4{ }^{\circ} \mathrm{C}$ until analysis. The analysis was performed within four to five hours after sampling.

The general chemical composition including fat, solids-not-fat (SNF), protein, lactose, and total solid (TS) were determined with calibrated milk analyzer known as Milkoscan (Milkoscan FT1 of Foss, Denmark) at Haramaya University Dairy Technology Laboratory.

\subsection{Microbiological Tests}

The microbial tests considered were Standard Plate Count (SPC), Coliform Count (CC) and yeast and mould count (YMC) test. For determination of SPC, CC and YMC peptone water was sterilized by autoclaving at 121 ${ }^{\circ} \mathrm{C}$ for 15 minutes. The total plate count agar (Oxoid) was used for determination of total viable microorganisms and potato dextrose agar (PDA) was used for determination of YMC, while the violet red bile agar (VRBA), used for determination of CC (Richardson, 1985). For all tests, the media used were prepared according to the guidelines given by the manufacturers. Each analysis was made in duplicate and precision of the analysis was determined at $5 \%$ level.

\subsection{Statistical Analysis}

Data collected through survey were analyzed using simple descriptive statistics (i.e. means, frequency and percentage) by Statistical Package for Social Sciences Software (SPSS, version 20). On the other hand, data from microbial counts were first transformed into logarithmic values $\left(\log _{10}\right)$ before statistical analysis. Then, data on chemical composition and the transformed microbial count values were analyzed using General Linear Model (GLM) procedure of SAS version 9.0 (SAS, 2008). Mean separation was carried out using the Least Significant Difference (LSD) technique when analysis of variance shows significant differences between means and differences were considered significant at $\mathrm{P}<0.05$.

The following model was used for the analysis of the chemical composition and microbial quality of milk:

$$
\mathrm{Y}_{\mathrm{ij}}=\mu+\alpha_{\mathrm{i}}+\mathrm{e}_{\mathrm{ij}}
$$

Where, $Y_{\mathrm{ij}}$ : individual observation for each test; $\mu$ : the overall mean; $\alpha_{\mathrm{i}}$ : the effect of $\mathrm{i}$ source of milk (producers [farmers], collectors and consumers); $\mathrm{e}_{\mathrm{ij}}$ : the error term.

\section{Results and Discussions}

\subsection{Feed Resources and Feeding of Dairy Cattle}

The main feed sources of cattle in the study area were cereal crop residues, sorghum and maize Stover (Table 1). Grazing crop aftermath and hay was ranked as the second sources of feed for cattle followed by cultivated improved forage. The feeding system practiced was commonly stall feeding system in which individual households tether the animals around home stead or/and farm lands and offer feed. There was no communal grazing land in the study areas because of expansion of cultivation of land for crop production.

Table 1. The main feed sources for cattle in study areas as ranked by respondents

\begin{tabular}{ll}
\hline Type of animal feed & Rank \\
\hline Crop residues and maize Stover & $1^{\text {st }}$ \\
Grazing and hay & $2^{\text {nd }}$ \\
Cultivated improved forage & $3^{\text {rd }}$ \\
Agro-industrial by products & - \\
Concentrate(indicate the mix) & - \\
\hline
\end{tabular}




\subsection{Productive and Reproductive Performances of Cows}

Milk yield of local cows in the study areas varied from 1 to 4 liters per day with the mean milk yield of $1.96 \pm 0.05$ liters per cow/day. This result is in agreement with the result of Derese (2008), who reported daily milk yield of local cows in urban and peri-urban farms of west Shoa Zone as 2.0 and 1.61 liters of milk, respectively. This result is also comparable with that of Alganesh (2002) who reported 1.8 liters/cow/day for Horro cattle in eastern Wollega. But it is slightly higher than milk yield reported by Zelalem \& Ledin (2001) for local cows in the central highland of Ethiopia (1.59 liters/day/cow).

Table 2. Milk yield/day/cow of local cows in the study areas

\begin{tabular}{lllll}
\hline Location/kebeles & lactating cows & Minimum milk yield (liter) & Maximum milk yield (liters) & Mean milk yield (liter) \\
\hline Biftu Ganama & 42 & 1.00 & 4.00 & 1.90 \\
Oda Chafe & 43 & 1.00 & 3.50 & 1.93 \\
Waligalte Bali'na & 55 & 1.00 & 4.00 & 2.05 \\
\hdashline Overall mean & & $\mathbf{1 . 0 0}$ & $\mathbf{3 . 8 0}$ & $\mathbf{1 . 9 6}$ \\
\hline
\end{tabular}

\subsubsection{Lactation Length}

The average lactation length of local cows in Biftu Ganama, Odachafe and Waligalte Bali'na kebeles were 7.41, 6.95 and 7.09 months, respectively (Table 3). Overall mean lactation length of the present study was $7.15 \pm 1.79$ months which is similar to the finding of Derese (2008) and Zelalem and Ledin (2001) who reported 7.20 and 7.77 months, respectively for the central highland of Ethiopia but less than that reported by Alganesh (2002) and Lemma (2004) (9.6 and 9.5 months, respectively) reported for eastern Wollega and eastern Shoa Zones, respectively.

\subsubsection{Calving Interval (CI)}

Calving interval is intimately linked to the yearly production rotation that influences the amount of milk a cow is likely to produce in a given period of successive calving (Mukasa-Mugerwa, 1989). In the current study, the estimated calving intervals for local cows were 18.87, 20.17 and 18.29 months for Biftu Ganama, Oda Chafe and Waligalte Bali'na kebeles, respectively with overall mean of $18.82 \pm 2.41$ months. This result is similar with the finding of Derese (2008) who reported 20.6 and 19.8 months for peri-urban and urban local breed of west Shoa zone, respectively. But, longer than the findings of Kedija (2007) who reported overall mean calving interval of local cows as $16.01 \pm 0.49$ months in Mi'esso district and Kefena (2004) reported calving interval of $16.04 \pm 0.85$ months for Boran crossbred cows.

\subsubsection{Age at First Calving (AFC)}

The respondents in the study area reported that the overall mean AFC for the local breeds was 49.95 months (Table 3), which is longer than the mean value of 43.2 months reported for tropical cows found in a number of traditional cattle production systems (Mukasa-Mugerwa, 1989). However, it is shorter than the finding of Alganesh (2002) and Asaminew (2007) who reported 57.3 and 57.12 months for Horro cattle of eastern Wollega and for the local cows in Bahir Dar town, respectively. First calving marks the starting of a cow's productive life and influences both the productive and reproductive life of the female, directly through its effect on her lifetime calf produce and milk production, and indirectly through its influence on the cost invested for up-bringing (Mukasa-Mugerwa, 1989).

Table 3. Reproductive performance of local cows in the study area

\begin{tabular}{lllll}
\hline Rural Kebeles & \multicolumn{5}{l}{} \\
\hline Variables & Biftu Ganama Mean \pm SD & Oda Chafe Mean \pm SD & Waligalte Bali'na Mean \pm SD & Over all Mean \pm SD \\
\hline Lactation length & $7.41 \pm 2.45$ & $6.95 \pm 1.23$ & $7.09 \pm 1.70$ & $7.15 \pm 1.79$ \\
Calving interval & $18.87 \pm 2.19$ & $20.17 \pm 1.95$ & $18.29 \pm 1.66$ & $18.82 \pm 2.41$ \\
Age at first calving & $50.00 \pm 4.37$ & $52.95 \pm 3.06$ & $47.85 \pm 3.62$ & $49.95 \pm 3.68$ \\
\hline
\end{tabular}

Note. SD: standard deviation. 


\subsection{Constraints to Dairy Production}

Majority of the respondent farmers ranked feed shortage as the $1^{\text {st }}$ most important problem contributing for low milk yield and low milk productivity of cows in the study areas (Table 4). Similar finding was reported by Derese (2008) for urban and peri-urban areas of west Shoa Zone. Fayo (2006) also reported feed shortage as the major constraint attributed to low production and productivity of cattle in and around Dire Dawa town. Similarly, Alemayehu (2002) and Kefena (2004) reported that nutrition is the most important constraint to milk production in Ethiopia. The respondents in the study areas also reported lack of grazing lands.

Table 4. Dairy production constraints as ranked by respondents

\begin{tabular}{ll}
\hline Production constraints & Rank \\
\hline Lack of grazing land & $2^{\text {nd }}$ \\
Feed shortage & $1^{\text {st }}$ \\
Lack of clean water & $3^{\text {rd }}$ \\
Lack of government recognition and commitment to dairy sector & $4^{\text {th }}$ \\
Lack of high yielding cattle breeds & $5^{\text {th }}$ \\
No or limited access to artificial insemination/inbreeding & $6^{\text {th }}$ \\
Shortage of capital & $7^{\text {th }}$ \\
\hline
\end{tabular}

\subsection{Sanitary Condition of Milk}

\subsubsection{Milking Practices}

All the households milk cow using hand milking after calf suckling to stimulates milk let-down. In the study areas occasionally cow could be milked without calf suckling whenever the calf is lost due to death. All household milk producers are milking cows twice a day (morning and evening) while the cows are in a house or under a tree shade (Table 5). All household milk producers were not regularly wash and clean the udder and teats of cows before milking but only whenever the cow get contaminated with dung. But Teshome (2013) reported that $72 \%$ of household milk producers in Shashemene town used to wash cows' teats and udder before milking while $28 \%$ did not wash cows' teats and udder before milking.

Table 5. Milking procedure followed by milk producers household in the study areas $(\mathrm{N}=122)$

\begin{tabular}{|c|c|c|}
\hline Variables & Frequency $(\mathrm{N})$ & $\%$ \\
\hline \multicolumn{3}{|l|}{ Milking stimulation } \\
\hline Washing teat & 1 & 0.8 \\
\hline Calf suckling & 121 & 99.2 \\
\hline \multicolumn{3}{|l|}{ Frequency of milking } \\
\hline Twice a day & 122 & 100.0 \\
\hline \multicolumn{3}{|l|}{ Practice of washing the udder and teats before milking } \\
\hline Yes some times when cows contaminated with dung & 122 & 100.0 \\
\hline \multicolumn{3}{|l|}{ Use of towel while cleaning the udder } \\
\hline Not at all & 122 & 100.0 \\
\hline \multicolumn{3}{|l|}{ Milker hygiene } \\
\hline \multicolumn{3}{|l|}{ Washing hands with soap before milking } \\
\hline Yes & 2 & 1.6 \\
\hline No & 120 & 98.4 \\
\hline \multicolumn{3}{|l|}{ Cleaning containers before and after milking } \\
\hline Yes & 122 & 100.0 \\
\hline \multicolumn{3}{|l|}{ Cover hair while milking and milk handling } \\
\hline Yes & 122 & 100.0 \\
\hline
\end{tabular}

Note. $\mathrm{N}$ : number of respondents. 


\subsubsection{Milk Handling Practices}

In Ethiopia, there is no standard hygienic condition followed by producers during milk production. The hygienic conditions are different according to the production system, adapted practices, level of awareness, and availability of resources (Zelalem, 2003). Similarly in the study area, traditional hand milking was the common practice. Containers used for milking, collection and transportation of milk by producers and sellers were different (Table 6). Most of them used plastic container, plastic jerry-cans, gourd (qabe) and the rest few used stainless steel. All (100\%) of the milk collection centers and $81.96 \%$ of producers used plastic jerry cans to transport milk to collection center. According to Teshome (2013) all dairy cooperative milk collection centers, $70.83 \%$ hotels, $75 \%$ small shops/kiosks and $84.62 \%$ small scale milk producers used plastic buckets for milk collection and about $20.83 \%$ hotels, $16.67 \%$ small shops/kiosks and $10.26 \%$ small scale milk sample producers of the respondents used plastic jars (jerry-cans) for milk collection in Shashemene town.

All respondents used to smoke milking utensil or utensil used for milk delivery to collection centers. They claimed that smoking is used to develop desirable flavor in the milk, and Mogessie and Fekadu (1993) confirmed that smoking has anti-microbial activity that inhibits growth of microorganisms in milk.

Table 6. Types of milk containers and handling practices in the study areas $(\mathrm{n}=132)$

\begin{tabular}{|c|c|c|c|}
\hline \multirow{2}{*}{ Variable } & Pro $(\mathrm{N}=122)$ & Coll $(\mathrm{N}=4)$ & Con $(\mathrm{N}=6)$ \\
\hline & $\mathrm{N}$ (Percent) & N (Percent) & $\mathrm{N}$ (Percent) \\
\hline \multicolumn{4}{|l|}{ Containers used for milking } \\
\hline Plastic buckets & $51(41.8)$ & - & - \\
\hline Qabe & $69(56.6)$ & - & - \\
\hline Stainless steel & $2(1.6)$ & - & - \\
\hline \multicolumn{4}{|l|}{ Containers used for milk delivery } \\
\hline Plastic buckets & $17(13.93)$ & & \\
\hline Plastic jars (jerry-cans) & $100(81.96)$ & & \\
\hline Qabe & $3(2.46)$ & & \\
\hline Stainless steel & $2(1.64)$ & & \\
\hline \multicolumn{4}{|l|}{ Containers used for milk collection } \\
\hline Plastic jars (jerry-cans) & & $4(100)$ & - \\
\hline Plastic bottle & - & - & $6(100)$ \\
\hline \multicolumn{4}{|l|}{ Methods of cleaning milk containers } \\
\hline Washing using ground water and smoking & $96(78.7)$ & $4(100)$ & $6(100)$ \\
\hline Washing using spring water and smoking & $26(21.3)$ & - & - \\
\hline \multicolumn{4}{|l|}{ Source of water } \\
\hline Ground water & $90(73.8)$ & 100 & - \\
\hline Spring water & $26(21.3)$ & - & - \\
\hline Tap water & $6(4.9)$ & - & \\
\hline \multicolumn{4}{|l|}{ Adulterations of milk with water } \\
\hline Yes & $56(45.9)$ & - & - \\
\hline No & $66(54.1)$ & - & - \\
\hline
\end{tabular}

Note. Pro: producer; coll: collection center; con: consumer; $\mathrm{N}=$ number of respondent.

\subsection{Milk Consumption, Market Channel and Price}

\subsubsection{Milk Consumption}

As the case in many parts of the country, milk is a part of the diet for people in the study areas. Milk is consumed either as fresh or boiled with tea which is locally called 'hoja'. In the current study areas, the majority of fresh milk produced was sold by the farmers (Table 7). This indicates that the objective of milk production in the study area was to generate cash income through sale of fresh milk. There was no processing of milk in to dairy products such as butter and cottage cheese in the study areas. There was high demand for fresh milk marketing and there was no seasonal effect on milk marketing. 
Table 7. The household milk utilization and consumption priority in study area

\begin{tabular}{ll}
\hline Variable & Percent of respondent \\
\hline Milk utilization & \\
Home consumption & 31.1 \\
Supply to local market & 68.9 \\
\hline Forms of consumption & 81.5 \\
In the form of 'hoja' & 18.5 \\
Raw milk (with porridge called marqa) & 32.78 \\
\hline Consumer priority & 33.61 \\
Children & 16.40 \\
Husband & 17.21 \\
Wife & \\
Youngsters (female + male ) &
\end{tabular}

\subsubsection{Market Channel and Price}

As it is common in other African countries, dairy products in Ethiopia are channeled to consumers through both formal and informal dairy markets (Ahmed et al., 2003). An earlier study conducted in the highlands of Ethiopia indicated that informal fresh milk market involves direct delivery of raw milk by producers to consumers in the immediate neighborhood and sale to traders or individuals in the nearby towns (Hollowey et al., 2000).

Accordingly, the channel of milk marketing in the study area follows the following two ways:

$$
\begin{aligned}
& \text { I. Producer } \rightarrow \text { Consumers }(13.1 \%) \\
& \text { II. Producers (faraqa annani) } \rightarrow \text { Collectors } \rightarrow \text { Wholesalers } \rightarrow \text { retailers }(86.9 \%)
\end{aligned}
$$

There was no formal milk marketing system in the study area. But the smallholder farmers sold fresh milk through milk association locally known as faraqa annani (milk shift) in which 5-10 women forms a group/team and pool together equal amount of milk. Then one of the team member of faraqa annani collect the daily milk and delivery it to milk collection centers. In this way all the member turn by turn deliver the milk to milk collection centers or directly sell to consumers or to retailers, and the money belongs to the respective member on that particular day. Then the milk collectors delivered the milk to whole seller in the nearby town. Finally, the whole sellers deliver the milk to different retailers in major towns like Dire Dawa, Haramaya, Awaday and Harar. The marketing system observed in this study is comparable with the finding of Fayo (2006) who reported the absence of formal milk marketing in urban and peri-urban areas of Dire Dawa.

In the current study there was no processing of milk into different dairy products such as butter and cottage cheese. This result is agreement with the findings of Mohammed (2003) who reported that most of the farmers in Harar region prefer to sell fresh milk because of its high demand and the less labor involved. According to the same author, fresh milk marketing through milk associations or groups is the dominant feature in Harar milk shed. In the rural Harar region, about $66 \%$ of the farmers deliver milk through milk associations and the rest $34 \%$ deliver milk on their own.

On the other hand, different survey reports indicated that selling of fresh milk is not common in the central highlands of Ethiopia, eastern Wollega and eastern Shewa due to inadequate amount of milk produced, cultural restrictions, distance from market areas and short shelf life of fluid milk (Zelalem \& Ledin, 2001; Alganesh, 2002; Lemma, 2004). These authors indicated that butter and Ayib (Ethiopian cottage cheese) are the common marketable dairy products in these areas.

The prices of milk vary among the different sources (Table 8). On average the price of milk at smallholder farmer (milk producers), milk collector, and wholesaler were 7.5, 15 and 20 Ethiopian birr per liter, respectively. The selling prices of raw milk at smallholder farmer (producers) were cheaper than the other two sources. Long distance from the market, poor access to information about milk marketing, lack of transportation, inappropriate collection centers and low price of milk hampered milk marketing in the rural regions of the study areas. Informal system is characterized by absence of licensing requirement to operate, low cost of operations, no rule to operate and producers' opportunities of getting higher price compared to the formal market (Ahmed et al., 2003). In study area milk producers are not satisfied with the current milk selling price; because of this they are 
adulterating the milk with water to increase volume and thereby to fetch equivalent money from the same amount of milk.

Table 8. Milk market channel and price

\begin{tabular}{ll}
\hline Milk source for market & Average milk price per litter in ETB \\
\hline Producer & 7.5 \\
Collector & 15 \\
Whole seller & 20 \\
\hline
\end{tabular}

\subsubsection{Milk Marketing Constraints}

In the study area, the selling of fresh milk was the common practice. On contrary, Lemma et al. (2005) reported that many farmers did not sell fresh milk in Eastern Shoa zone and Eastern Wollega mainly due to shortage and cultural restriction. Milk marketing was virtually done by the women and young females. Limited access to market and lack of market information were reported as the major constraints for milk marketing in the study areas (Table 9).

Table 9. Fresh milk constraints in the study areas ranked by respondents

\begin{tabular}{ll}
\hline Marketing related problems & Rank \\
\hline Lack of market information & $2^{\text {nd }}$ \\
Low price of fresh whole milk & $4^{\text {th }}$ \\
Limited access to market & $3^{\text {rd }}$ \\
Distance from market or milk collectors & $1^{\text {st }}$ \\
Low daily milk yield per cow and farm & $5^{\text {th }}$ \\
Poor quality milk delivered to milk collector & $7^{\text {th }}$ \\
Increasing feed prices & $6^{\text {th }}$ \\
\hline
\end{tabular}

\subsection{Chemical Composition of Cow's Milk in the Study Area}

The fat, protein, total solids, SNF and lactose percentages at producers' level were significantly higher $(\mathrm{P}<0.05)$ than that of consumers and milk collection centers (Table 10). The variation may be attributed to whole milk collected from producers immediately after milking without being adulterated and contaminated. According to sampled respondents adulteration of milk with water starts at the producers' level when they collect the milk for "faraqa annani" and the collection centers also add some water to the collected milk at selling and buying site. Milk samples collected from the producers meet international standard in terms of chemical composition, but milk samples from collectors and consumers did not.

Table 10. Mean $( \pm$ SE) chemical composition of raw cows milk

\begin{tabular}{lllll}
\hline \multirow{2}{*}{ Variables } & Farmer N $=28$ & Collection center N = 4 & Consumer N =6 & Over all mean \\
\cline { 2 - 5 } & Mean \pm SE & Mean \pm SE & Mean \pm SE & Mean \pm SE \\
\hline Protein (\%) & $3.55 \pm 0.05^{\mathrm{a}}$ & $2.82 \pm 0.026^{\mathrm{b}}$ & $3.09 \pm 0.13^{\mathrm{b}}$ & $3.40 \pm 0.068$ \\
Fat (\%) & $6.81 \pm 0.32^{\mathrm{a}}$ & $4.58 \pm 0.85^{\mathrm{b}}$ & $4.61 \pm 0.45^{\mathrm{b}}$ & $6.23 \pm 0.29$ \\
Total solids (\%) & $15.61 \pm 0.41^{\mathrm{a}}$ & $9.5 \pm 0.40^{\mathrm{b}}$ & $10.28 \pm 0.39^{\mathrm{b}}$ & $14.12 \pm 0.51$ \\
Solids-not-fat (SNF) (\%) & $8.56 \pm 0.11^{\mathrm{a}}$ & $7.01 \pm 0.15^{\mathrm{b}}$ & $7.5 \pm 0.16^{\mathrm{b}}$ & $8.23 \pm 0.12$ \\
Lactose (\%) & $4.88 \pm 0.11^{\mathrm{a}}$ & $3.30 \pm 0.24^{\mathrm{b}}$ & $3.42 \pm 0.11^{\mathrm{b}}$ & $4.48 \pm 0.14$ \\
\hline
\end{tabular}

Note. N: number of milk samples; SE: Standard Error.

The overall mean fat (6.23\%) percentage of raw cows' milk obtained in the present study is greater than the fat percent of 5.6\% reported for Zebu cows' milk (O'Connor, 1994) and the fat content of whole milk collected from smallholder framers in eastern Wollega (6.05\%) (Alganesh, 2002). The variation in fat percentage observed in 
the present study may probably be due to variation in cow breed, stage of lactation, feeding regime, individual condition of cow, and parity.

SNF content of milk from producer mean $8.56 \%$ is almost similar to the finding of Teshome (2013) who reported $(8.4 \pm 00)$ SNF for milk producer small scale farms in Shashemene town. However, this result is less than the finding of Teklemichael (2012) $(8.75 \pm 0.301 \%)$ for milk obtained from dairy farms in Dire Dawa town. According to European Union quality standards for unprocessed whole milk, SNF content should not be less than $8.5 \%$ (Tamime, 2009) and Food and Drug Administration (FDA) quality standards, a minimum SNF content of whole milk is $8.25 \%$ (Raff, 2011). Accordingly, the average SNF content (8.23\%) observed from three milk samples was almost within the recommended international standards.

\subsection{Microbial Quality of Raw Cow Milk in the Study Areas}

Total bacterial count (TBC), coliform count (CC), and yeast and mould count (YMC) were analyzed to assess microbial quality of milk in the study areas (Table 11). Mean TBC was significantly $(\mathrm{P}<0.05)$ higher at milk collection centers than that of the producers and consumers. This might be due to further contamination of the milk during transportation, use of poorly cleaned milk containers, mixing of milk from different sources, delay for 3-4 hours after collection, adulteration of milk with water, and absence of cooling facilities at milk buying and selling points. TBC obtained in this study is generally high compared to the acceptable level of $1 \times 10^{5}$ bacteria per $\mathrm{mL}$ of raw milk (O'Connor, 1994). In general, producers use plastic jerry can for milk collection and keep raw milk at room temperature until they sell out to milk collection centers which may lead to high number of total bacterial count. Higher TBC of milk samples obtained from producers could be attributed to failure to wash udder and teat before milking, improper cleaning of containers before and after milking, failure to use towel for hands drying and other unhygienic milking practices.

In the present study, TBC of raw milk collected from milk producers (farmers) $\left(6.11 \log _{10} \mathrm{cfu} / \mathrm{mL}\right)$ was $\operatorname{lower}$ than that reported by Teshome (2013), Debebe (2010), and Ahmed et al. (2008) who found high total bacterial count of $\left(6.62 \pm 0.051 \log _{10} \mathrm{cfu} / \mathrm{mL}\right)$ milk samples collected from small scale milk producers of Shashemene town, $\left(6.98 \pm 0.15 \log _{10} \mathrm{cfu} / \mathrm{mL}\right)$ in milk samples collected from milk producers in and around Addis Ababa City and $\left(9.089 \pm 0.281 \log _{10} \mathrm{cfu} / \mathrm{mL}\right)$ in milk samples collected from dairy farms of Khartoum State.

Table 11. (Mean \pm SE) microbial counts $(\log 10 \mathrm{cfu} / \mathrm{mL})$ of raw cow milk in the study areas

\begin{tabular}{lllll}
\hline \multirow{2}{*}{ Variables } & \multicolumn{3}{c}{ Milk Sources } \\
\cline { 2 - 5 } & Producers $(\mathrm{n}=28)$ & Milk Collectors $(\mathrm{n}=4)$ & Consumer $(\mathrm{n}=6)$ & Overall mean \\
\cline { 2 - 5 } & Mean $\pm \mathrm{SE}$ & Mean $\pm \mathrm{SE}$ & Mean $\pm \mathrm{SE}$ & Mean $\pm \mathrm{SE}$ \\
\hline TBC & $6.11 \pm 0.047^{\mathrm{b}}$ & $6.89 \pm 0.01^{\mathrm{a}}$ & $6.23 \pm 0.02^{\mathrm{b}}$ & $6.21 \pm 0.05$ \\
$\mathrm{CC}$ & $4.70 \pm 0.10^{\mathrm{b}}$ & $5.29 \pm 0.04^{\mathrm{a}}$ & $5.04 \pm 0.02^{\mathrm{ab}}$ & $4.82 \pm 0.08$ \\
YMC & $3.77 \pm 0.09^{\mathrm{b}}$ & $4.52 \pm 0.16^{\mathrm{a}}$ & $4.11 \pm 0.04^{\mathrm{ab}}$ & $3.90 \pm 0.08$ \\
\hline
\end{tabular}

Note. CC: Coliform count; $\mathrm{n}$ : number of milk samples; SE: standard error; TBC: Total bacterial count; YMC: yeast and mould count.

Significantly higher CC was recorded for milk sample taken from milk collectors as compared to that of producers (Table 11) but there was no significance difference between sample from milk collectors and consumers. The overall mean CC for raw cow milk $\left(4.82 \log _{10} \mathrm{cfu} / \mathrm{mL}\right)$ in this study is higher than that reported by Kurwijila et al. (1992) from Tanzania $\left(10^{5} \mathrm{cfu} / \mathrm{mL}\right)$, Ombui et al. (1995) from Kenya $\left(10^{4} \mathrm{cfu} / \mathrm{mL}\right)$, and Abdalla and Elhagaz (2011) from Khartoum $\left(2.23 \log _{10} \mathrm{cfu} / \mathrm{mL}\right)$. But it is in agreement with the findings of Teshome (2013), Derese (2008), Asaminew (2007), from Ethiopia who reported a CC of $5 \log _{10} \mathrm{cfu} / \mathrm{mL}$ milk sample collected from Shashemene town, $4.84 \log _{10} \mathrm{cfu} / \mathrm{mL}$ in milk samples collected from West Shewa zone of Oromia region and $4.49 \log _{10} \mathrm{cfu} / \mathrm{mL}$ milk samples collected from Bahir Dar milk shed. In the other study, Zelalem and Faye (2006) obtained higher CC of $6.57 \log _{10} \mathrm{cfu} / \mathrm{mL}$ for raw cow's milk collected from different producers in the central highland of Ethiopia.

Coliform bacteria could contaminate milk from manure, bedding materials, contaminated water, soil and inadequately cleaned milking utensils (Van den Ben, 1988). A study conducted on raw milk from a dairy farm in Hawassa indicated an initial coliform count of $10 \mathrm{cfu} / \mathrm{mL}$ in sterile containers. This reached a level of $10^{8} \mathrm{cfu} / \mathrm{mL}$ within 24 hours (Mogossie \& Fekadu, 1993). In the current study area, some animals are kept in muddy barn and 
poor hygienic conditions. This possibly has exposed the milk to high level of contamination, which in turn increase the microbial count.

Yeast and mould are considered to be spoilage microorganisms. Milk from collectors had significantly higher (P $<0.05)$ YMC than that of milk samples from the producers (Table 11). According to Malaysia food quality standards, YMC in raw milk samples should be lower than $2.1 \log _{10} \mathrm{cfu} / \mathrm{mL}$ (Torkar \& Vengust, 2008). However, the mean values of YMC found in the current study at all levels were higher than this set maximum YMC. YMC found in this study is lower than the finding of Teshome (2013) and Haile et al. (2012) who reported higher YMC of $4.206 \log _{10} \mathrm{cfu} / \mathrm{mL}$ for samples collected from Shashemene town and $4.65 \log _{10} \mathrm{cfu} / \mathrm{mL}$ for milk samples collected from storage containers and $7.13 \log _{10} \mathrm{cfu} / \mathrm{mL}$ for milk samples collected from distribution containers in Hawassa, Southern Ethiopia.

The high YMC observed in milk obtained from milk collector might be attributed to contamination from dust, air, containers, water used, poor personal hygiene, and poor hygiene of milk selling environment. The presence of yeasts and moulds in milk samples collected from the producers, consumers and collection centers is higher than the acceptance levels of yeast and moulds in raw milk.

\section{Conclusions}

We found that shortage of feed was one of the major bottlenecks for the development of dairy sector in the study areas. The selling prices of raw milk at farmers level were very low and cheaper than the other three sources which enforce the producers to adulterate the milk with water to compensate low price. Poor hygienic condition of the milking environment and milk containers, absence of udder and teats cleaning practices, failure to use towel for udder washing and drying, and poor personal hygiene of the milkers were contributed for poor and substandard microbial quality of milk in the study areas. Hence extension services aimed at improving feed resource and feeding system to increase milk production and productivity should be the primary intervention agenda. Establishment of dairy cooperatives that collect milk from farmers at fair price and facilitate milk marketing could solve problem of low milk price at farmer level. Introduction of milk quality test methods and quality based payment could also be used to control and improve milk quality in the study areas.

\section{References}

Abdalla, M. O., \& Elhagaz, F. M. (2011). The Impact of Applying Some Hygienic Practices on Raw Milk Quality in Khartoum State, Sudan. Research Journal of Agriculture and Biological Sciences, 7(2), 169-173.

Ahmed, M. M., Ehui, S., \& Yemesrach, A. (2003). Dairy development in Ethiopia. Socioeconomics and policy research (Working Paper, 58, p. 47). ILRI (International Livestock Research Institute), Nairobi, Kenya.

Ahmed, M. M., El Zubeir, E. M., El Owni, A. O., \& Ahmed, A. M. (2008). Assessment of Microbiological Loads and Antibiotic Residues in Milk Supply in Khartoum State, Sudan. Research Journal of Dairy Sciences, 2(3), 57-63.

Alemayehu, M. (2002). Forage production in Ethiopia: A case study with implications for livestock production (pp. 45-56). Ethiopian Society of Animal Production, Addis Ababa, Ethiopia.

Alganesh, T. (2002). Traditional milk and milk products handling practice and raw milk quality in Eastern Wollega (M.Sc. Thesis, Almaya University, Dire Dawa, Ethiopia).

Asaminew, T. (2007). Production, handling, traditional processing practices and quality of milk in Bahir Dar milk shed Area, Ethiopia (M.Sc.Thesis, Alemaya University, Ethiopia).

Azage, T., Gebremedhin, B., Hoekstra, D., Belay, B., \& Yosef, M. (2013). Smallholder dairy production and marketing systems in Ethiopia: IPMS experiences and opportunities for market-oriented development [IPMS (Improving Productivity and Market Success) of Ethiopian Farmers Project Working Paper, 31, p. 4]. Nairobi: ILRI.

Belete, A. (2006). Studies on cattle milk and meat production in fogera Woreda: production systems, constraints Opportunities for development (M.Sc. Thesis, Debub University, Awasa, Ethiopia).

CSA (Federal Democratic Republic of Ethiopia Central Statistics Authority). (2014). Agricultural Sample Survey II. Report on Livestock and Livestock Characteristics. Statistical Bulletin. Addis Ababa, Ethiopia.

Debebe, W. (2010). Physicochemical Properties and Safety of Street-vended Milk in and Around Addis Ababa City (Kotebe, Bishoftu and Chancho) (M.Sc. Thesis, Haramaya University, Ethiopia).

Derese, T (2008). Present situation of urban and peri-urban milk production and quality of raw milk produced in West Shewa Zone, Oromia Region (M.Sc. Thesis, Haramaya University, Haramaya, Ethiopia). 
Fayo, D. (2006). Assessment of Milk Production, Marketing, Feeds and Feeding System of Dairy Cows in and Around Dire Dawa Town (M.Sc. Thesis, School of Graduate Studies, Alemaya University).

FSA (Food Standards Agency). (2006). Milk Hygiene on the Dairy Farm. Practical Guides for Milk Producers, England.

Haile, W., Zelalem, Y., \& Yosef, T. G. (2012). Hygienic Practices and Microbiological Quality of Raw Milk Produced under Different Farm Size in Hawassa, Southern Ethiopia. Agricultural Research and Reviews, 1(4), 132-142.

Holloway, G. C., Nicholson, C., Delgado, C., Staal, S., \& Ehui, S. (2000). How to make milk market: A case study from the Ethiopian highlands (p. 28, Socio-economic and Policy Research Working Paper 28). International Livestock Research Institute (ILRI), Nairobi, Kenya.

Karmen, G. T., \& Slavica, G. T. (2008). The Microbiological Quality of Raw Milk after introducing the two Day’s milk collecting system. Acta Agriculturae Slovenica, 92(1), 61-74.

Kedija, H. (2007). Characterization of milk production system and opportunity for market orientation: A case study of Mieso district, Oromia region, Ethiopia (M.Sc. thesis, Haramaya University, Ethiopia).

Kefena, E. (2004). Analysis of longevity, productive herd life and lifetime production of Boran crossbred cows with various levels of exotic inheritance in the central highland of Ethiopia (p. 83, M.Sc. thesis, School of Graduate Studies, Alemaya University).

Kurwijila, R. L., Hansen, K. K., Macha, I. E., Abdallah, K., \& Kadigi, H. J. S. (1992). The bacteriological quality of milk from hand and machine milked dairy herds in Morongo, Tanzania. Journal of African Livestock Research, 2, 59-67.

Lemma, F. (2004). Assessment of butter quality and butter making efficiency of new churns compared to smallholders' butter making techniques in east Shoa Zone of Oromia, Ethiopia (p. 113, M.Sc. thesis, Alemaya University of Agriculture, Dire Dawa, Ethiopia).

Lemma, F., Fekadu, B., \& Hegde, P. B. (2005). Rural smallholder milk and milk products production, utilization and marketing systems in three districts of East Shoa Zone of Oromia. Proc. of the 12th Annual Conference of the Ethiopian Society of Animal Production (ESAP) (Vol. 2, pp. 29-37).

Meta District Livestock Office. (2015). The role of village dairy co-operatives in dairy development, prospects for dairy improving in Ethiopia. Ministry of Agricultural, Addis Ababa, Ethiopia.

Mogessie, A., \& Fekadu, B. (1993). Microbial load, micro flora, and keeping quality of raw and pasteurized milk from a dairy farm. Bull. Animal Health and Production in Africa, 42, 55-59.

Mohammed, Y. K. (2003). Certain aspects of the dairy systems in the Harari milk shed, eastern Ethiopia (p. 195, $\mathrm{PhD}$. thesis, School of Graduate Studies, University of the Free State, South Africa).

Mukasa-Mugerwa, E. (1989). A review of reproductive performance of Bos indicus cattle. ILCA Monograph No. 6, Addis Ababa, Ethiopia.

O’Connor, C. B. (1994). Rural Dairy Technology (p. 133, ILRI Training Manual No. 1). International Livestock Research Institute (ILRI), Addis Ababa, Ethiopia.

Ombui, J. N., Arimi, S. M., Mcdermott, J. J., Mbugua, S. K., Githua, A. A., \& Muthoni, J. (1995). Quality of raw milk collected and marketed by dairy cooperative societies in Kiambu District, Kenya. Bull. Animal Health and Production in Africa, 43, 277-284.

Raff, H. (2011). Market implications of changing fat content of milk and dairy products, fat content and composition of animal products. Journal Food Science and Technology, 5(2), 6-17.

Richardson, G. H. (1985). Standard Methods for the Examination of Dairy Products (15th ed., pp. 168-196). American Public Health Association, Washington, D.C.

SAS (Statistical Analysis System). (2008). SAS Version 9.0.

SPSS (Statistical Procedures for Social Sciences). (2007). SPSS Version 20. SPSS, IBM.

Tamime, A. Y. (2009). Milk Processing and Quality Management. Society of Dairy Technology, United Kingdom.

Teklemichael, T. (2012). Quality and Safety of Raw and Pasteurized Cow Milk Produced and Marketed in Dire Dawa Town (M.Sc. thesis, Haramaya University, Ethiopia). 
Teshome, G. (2013). Physicochemical properties and microbial quality of raw cow's milk produced and marketed in Shashemene town, southern Ethiopia (M.Sc. thesis, Haramaya University, Ethiopia).

Torkar, K. G., \& Vengust, A. (2008). The Presence of Yeasts, Moulds and Aflatoxin M1 in Raw Milk and Cheese in Slovenia. Food Control, 19, 570-577. https://doi.org/10.1016/j.foodcont.2007.06.008

Van den, B. (1988). Dairy Technology in the Tropics (p. 209). Wagengen, The Netherlands.

Yamane, T. (1967). Statistics, an Introductory Analysis (2nd ed.). New York.

Zelalem, Y. (2003). Sanitary conditions and microbial qualities of dairy products in urban and peri-urban dairy shed of the central Ethiopia. DEA. Lyon, France.

Zelalem, Y. (2012). In M. L. R. S. Cunha (Ed.), Microbial Properties of Ethiopian Marketed Milk and Milk Products and Associated Critical Points of Contamination: An Epidemiological Perspective, Epidemiology Insights.

Zelalem, Y., \& Ledin, I. (2001). Milk production, processing, marketing and the role of milk and milk products on smallholder farmers income in the central highlands of Ethiopia. Proceedings of the 8th Annual Conference of the Ethiopia Society of Animal Production (ESAP) (pp. 139-154). Addis Ababa, Ethiopia.

\section{Copyrights}

Copyright for this article is retained by the author(s), with first publication rights granted to the journal.

This is an open-access article distributed under the terms and conditions of the Creative Commons Attribution license (http://creativecommons.org/licenses/by/4.0/). 